\title{
高電圧沪紙電気泳動-蛍光分析法による微量サマリウム, ユウロピウムの分離及び定量
}

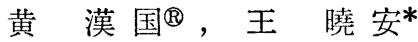

(1985 年 2 月 23 日受理)

\begin{abstract}
本報はクエン酸を電解液として，高電圧沪紙電気泳動法（HVPE）で希土類元素を分離，2-テノイル トリフルオロアセトンーフェナントロリン抽出蛍光法により分離されたサマリウム及びユウロピウムを 同時定量する方法について検討したＨVPE での希土類金属イオンの泳動距離と原子番号並びにイオ ン半径との相関は密接であり, 電压 $3000 \mathrm{~V}$, 泳動時間 25 分間で, $\mathrm{La}^{3+}-\mathrm{Ce}^{3+}-\mathrm{Pr}^{3+}-\mathrm{Nd}^{3+}-\mathrm{Sm}^{3+}$

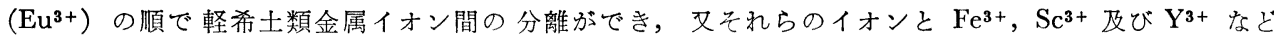
の金属イオンとの分離勃果もよかった．HVPE-蛍光法の併用により，20〜800 ng/10 ml の範囲でニウ ロビウムの回収率は $97.8 \%$ ，サマリウムは $94.0 \%$ であり，混合希土類金属酸化物に適用した結果， $0.023 \mu \mathrm{g}$ の酸化ニウロピウム (III) 及び $0.026 \mu \mathrm{g}$ の酸化サマリウム (III) が精度よく同時定量された.
\end{abstract}

\section{1 緒言}

汇紙電気泳動法による 希土類元素の 分離には, 主に $\mathrm{EDTA}^{1)}$ ，クエン酸12) あるいは $\alpha$-七ドロキシイソ酪酸 $(\alpha-\mathrm{HIBA})^{3) \sim 6)}$ が電解液として 使用されているが，電 気泳動分離後は汪とんど中性子放射化分析により定量が 行われている。しかし，その装置は高価ではん用できる ものではない，本報ではクェン酸を電解液として, 高電 圧沪紙電気泳動法 (HVPE) で希土類元素を分離, 2-テ ノイルトリフルオロアセトン (TTA)ーフェナントロリ ン (phen) 抽出蛍光法7)により分離されたサマリウム， ユウロピウムを同時定量する方法について検討した， HVPE と蛍光法の併用により, 蛍光法での $\mathrm{Fe}^{3+}, \mathrm{Sc}^{3+}$ 及び重希土類金属イオンなどに上る蛍光消光作用が排除 でき, 複雑な試料中のサマリウム, ニウロピウムの高感 度同時定量を可能とした。. 本法に用いられる試料は微量 で, 装置及び操作は簡易で, 所用時間も短く, 中性子放 射化分析より利点が多いと考学られる。

\section{2 実験}

\section{1 試 薬}

希土類金属イオン標準溶液は純度 $99.9 \sim 99.99 \%$ の酸 化物を $2 \mathrm{M}$ 塩酸に溶解し, 希土類金属イオン $1 \mathrm{mg} / \mathrm{ml}$ の溶液を調製した。このほかに $5 \times 10^{-5} \mathrm{M}$ TTA-5×

\footnotetext{
* 河北鉱冶学院 : 中華人民共和国河北省唐山市
}

$10^{-4} \mathrm{M}$ phen ベンゼン溶液, $0.05 \mathrm{M}$ クェン酸溶液 $(\mathrm{pH}$ $2.22), 0.2 \%$ アルセナソ III 水溶液, 飽和四ホウ酸ナ トリウム水溶液, $0.1 \mathrm{ppm}$ ローダミン $\mathrm{B}$ 水溶液などを使 用した。

\section{2 装}

電気泳動には北京市新技術応用研究所の GS-80A 高 電圧電気泳動装置 (出力電压: DG $0 \sim 5 \mathrm{kV}$, 出力電流: 0〜200 mA，水道水冷却方式）を使用した。

蛍光強度の 測定には 中国天津光学の WFD-9 型蛍光 分光光度計 $(150 \mathrm{~W}$ キセノンランプ, $\mathrm{R} 456$ 光電子增倍 管）を使用した。

\subsection{HVPE の一般操作}

2.3.1 電解液左右二つの電父泳動槽に艺れ艺れ $0.05 \mathrm{M}$ クエン酸溶液 $1500 \mathrm{ml}$ を加光, 両槽の液面はな るべく同じ水平に保った.

2.3.2 試料負荷 長さ $30 \mathrm{~cm}$, 幅 $5 \mathrm{~cm}$ のクロマト グラフィー用汇紙（中国杭州新華製紙所 No. 3) を電解 液に浸し, 均一に湿した後, 乾燥沪紙で余分の液を吸い 取り, あらかじめ絶縁材としてのポリエステル薄膜及び ポリテトラフルオロエチレン薄膜を敷いた下部冷却板に 水平に置き,ストリップの両端をそれぞれ約 $5 \mathrm{~cm}$ 汪ど 電解液に浸す。マイクロピペッターもしくはガラスキャ ピラリーで一定量 $(1 \sim 2 \mu \mathrm{l})$ の試料溶液を白金電極の陽 極の端から $5 \mathrm{~cm}$ のところを原点として沪紙上に負荷す 
る.

2.3.3 電気泳動 試料を負荷した沪紙をポリエステ ル薄膜, 更にそのトをポリテトラフルオロエチレン薄膜 で覆い, 上部冷却板をかぶせ，冷却水を通じて，所定の 電生に調節し, 一定時間通電する.

2.3.4 発色及び泳動距離の測定 電気泳動後の沪紙 を赤外ランプで迅速に乾燥させ，アルセナゾ III 溶液を 用いて発色させる. スポットの重心から原点の中心まで の距離を泳動距離 $(\mathrm{mm})$ とし, 陽極への泳動はマイナ ス, 陰極への泳動はプラスと記す。

2.4 抽出蛍光法によるサマリゥム，ユゥロピウムの 同時定量

電気泳動後発色された泳動図のサマリウム，ユウロ ピウムに該当する部分を切り抜き，それを $50 \mathrm{ml}$ ビー カーに入れる. 飽和四ホウ酸ナトリウム水溶液 $5 \mathrm{ml}$ 加光, $\mathrm{pH} 9.5$ に調節し, 溶液と沪紙とを共に分液漏斗 に移し, $5 \times 10^{-5} \mathrm{M}$ TTA-5 $\times 10^{-4} \mathrm{M}$ phen ベンゼン溶 液 $10 \mathrm{ml}$ を加兄, 30 分間振り混ぜ抽出する. その有機 相について, 波長 $341 \mathrm{~nm}$ の光で励起し, $614 \mathrm{~nm}$ の波 長に扣ける蛍光強度からユウロピウムを，650 nm での 蛍光強度からサマリウムを同時測定する。

\section{3 結果及び考察}

\subsection{HVPE による希土類元素の分離}

3.1.1 泳動時間及び 泳動電圧の影響 泳動時間及 び泳動電圧が増加すると, 各イオン間の分離はよくなる が, 本装置の冷却は常温に拉ける水道水冷却方式である ので, 電圧が $3500 \mathrm{~V}$ より大であると, ジュール効果に よる電解液の蒸発，沪紙の 発熱が著しくなる，そのた め, スポットの拡散が激しく, 分離がかえって悪くなる ので, 本法においては, 泳動電圧を $3000 \mathrm{~V}$ 以下, 泳動 時間を 30 分以内とした.

3.1.2 泳動距離と原子番号並びに 結晶イオン 半径と の関係希土類金属イオンの泳動距離は, 原子番号の 增大並びにイオン半径の減少につれて減少し, Fig. 1 亿 示したように，相互間には良好な直線性がある.

本実験に打けるクェン酸 $\left(\mathrm{p} K_{1}=3.14\right)$ 溶液中の主な 化学種は $\mathrm{H}_{2} \mathrm{Cit}^{-}$及び $\mathrm{H}_{3} \mathrm{Cit}$ なので, 三価希土類金属 イオン (RE) との錯体は主に $\left[\mathrm{RE}\left(\mathrm{H}_{2} \mathrm{Cit}\right)\right]^{2+}$ もく は $\left[\mathrm{RE}\left(\mathrm{H}_{2} \mathrm{Cit}\right)_{2}\right]^{+}$などの陽イオンとして存在している から, 通電した場合, それぞれのイオンは陰極へ泳動す る. ランタニド収縮のため, 希土類金属のイオン半径 が原子番号の増大に従って減少し, $\mathrm{H}_{2} \mathrm{Cit}^{-}$と形成さ れたキレートイオンの安定性も增大し, 泳動距離が短く

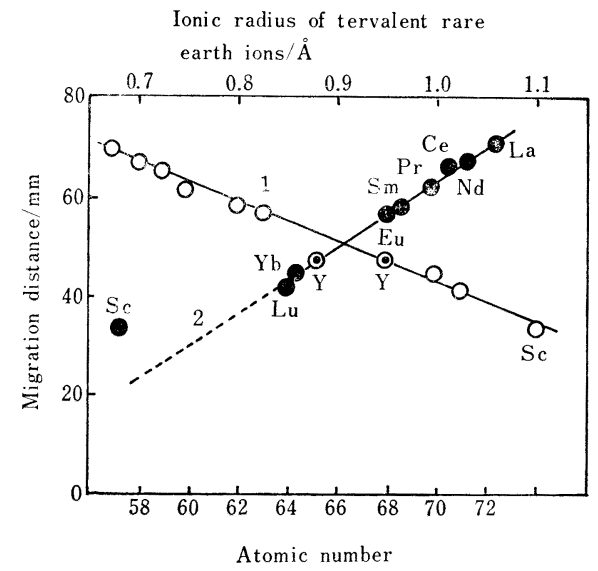

Fig. 1 Relation between migration distance and atomic number and ionic radius of rare earth ions

$1:$ Atomic number; $2:$ Ionic radius

なると考劣られる． $\mathrm{Y}^{3+}$ の泳動距離については, 文献1) によれば $\mathrm{Pr}^{3+}-\mathrm{Nd}^{3+}$ の間に位置し, 電解液が $\alpha-\mathrm{HIBA}$ の場合には $\mathrm{Dy}^{3+}-\mathrm{Ho}^{3+}$ の間3) に位置するが, 本実験 では, $\mathrm{Y}^{3+}$ は $\mathrm{Er}^{3+}$ の位置に当たり, 両イオンの半径 $\left(\mathrm{Y}^{3+}, \mathrm{Er}^{3+}\right.$ とも $\left.0.88 \AA\right)$ とよく一致している。 $\mathrm{Y}^{3+}$ は 重希土類に帰属すべきこと並びに泳動距離とイオン半 径との間に密接な相関性があることについて，本実験 の HVPE の結果からよく立証できた. イオン半径の 最も小さな $\mathrm{Sc}^{3+}$ のクエン酸とのキレートイオンは他の 希土類金属イオンから形成された錯イオンよりも安定 であるので, 泳動距離は最も小さい. $\mathrm{Sc}^{3+}$ の性質が他 の希土類金属イオンとは幾らかの違いがあることは, Fig. 1 の直線 2 から外れていることに反映している.

3.1.3 分離効果 クェン酸を電解液として, 泳動電 圧 $3000 \mathrm{~V}$, 泳動時間 25 分で, $\mathrm{La}^{3+-} \mathrm{Ce}^{3+}-\mathrm{Pr}^{3+}-\mathrm{Nd}^{3+}$ $\mathrm{Sm}^{3+}\left(\mathrm{Eu}^{3+}\right)$ の順で軽希土類金属イオン間の分離がで き, 又とれらのイオンと $\mathrm{Y}^{3+}, \mathrm{Lu}^{3+}$ などの重希土類金 属イオン $-\mathrm{Sc}^{3+}-\mathrm{Fe}^{3+}$ との分離も Fig. 2 に示したよう に達成された. 特に, $\mathrm{Fe}^{3+}$ とクェン酸とのキレート形 成が非常に強く, 本実験の 条件下では [Fe(HCit) $)_{2}$ もしくは $\left[\mathrm{FeCit}_{2}\right]^{3-}$ として陽極の方向へ泳動する $(1000 \mathrm{~V}, 30$ 分では $+57 \mathrm{~mm}$ 泳動する) ので, HVPE による $\mathrm{Fe}^{3+}-\mathrm{Sc}^{3+}$ - 希土類金属イオンとの分離は完全に 実現され，後の蛍光法測定では非常に有利であった。 エン酸及び $\alpha$-HIBA を電解液とした場合の分離効果を Table 1 及び 2 に示した. 
Table 1 Separation effect of tervalent rare earth ions using citric acid as electrolyte

\begin{tabular}{|c|c|c|c|c|c|c|c|}
\hline \multirow{2}{*}{$\begin{array}{l}\text { Conditions of } \\
\text { electrophoresis }\end{array}$} & \multicolumn{5}{|c|}{ Migration distance between $/ \mathrm{mm}$} & \multirow{2}{*}{ Remark } & \multirow{2}{*}{ Ref. } \\
\hline & $\mathrm{La}-\mathrm{Ce}$ & $\mathrm{Ce}-\mathrm{Pr}$ & $\mathrm{Pr}-\mathrm{Nd}$ & $\mathrm{Nd}-\mathrm{Sm}$ & $\mathrm{Sm}-\mathrm{Eu}$ & & \\
\hline $1 \%, 300 \mathrm{~V}, 45 \mathrm{~min}$ & 9 & \multicolumn{2}{|c|}{$7(\mathrm{Ge}-\mathrm{Nd})$} & 4 & - & Sc-Fe, Y-Nd n.s. $\dagger$ & 2) \\
\hline $0.05 \mathrm{M}, 300 \mathrm{~V}, 3 \mathrm{~h}$ & 20 & 9 & 8 & 14 & - & Y-Nd n.s. & 1) \\
\hline $0.05 \mathrm{M}, 3000 \mathrm{~V}, 25 \mathrm{~min}$ & 21 & 13 & 8 & 15 & 4 & Fe-Sc-Y- light R.E. sep. $† \dagger$ & This paper \\
\hline
\end{tabular}

$\dagger$ Not separated; †† Separated completely

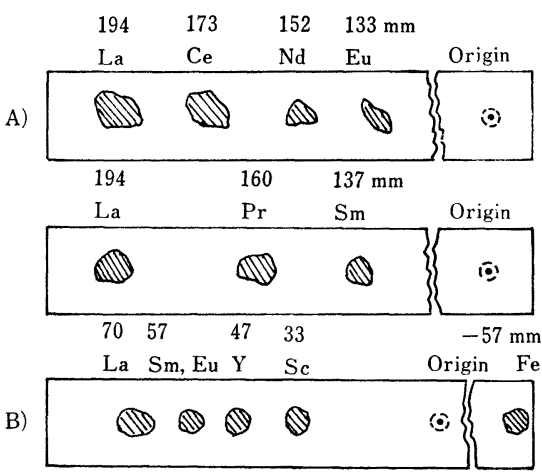

Fig. 2 Chromatograms of rare earth ions $0.05 \mathrm{M}$ Citric acid ( $\mathrm{pH}$ 2.22) as electrolyte. A) $3000 \mathrm{~V}, 25 \mathrm{~min}$; B) $1000 \mathrm{~V}, 30 \mathrm{~min}$

Table 2 Comparison of separation factor between various electrolytes

\begin{tabular}{|c|c|c|c|c|c|c|c|}
\hline \multirow{2}{*}{$\begin{array}{l}\text { Conditions of } \\
\text { electrophoresis }\end{array}$} & \multicolumn{6}{|c|}{ Separation factor $\dagger$} & \multirow{2}{*}{ Ref. } \\
\hline & $\mathrm{La}$ & $\mathrm{Ce}$ & $\operatorname{Pr}$ & $\mathrm{Nd}$ & $\mathrm{Sm}$ & $\mathrm{Eu}$ & \\
\hline $\begin{array}{l}0.05 \mathrm{M} \mathrm{H} \mathrm{H}_{3} \mathrm{Cit} \\
3 \mathrm{kV}, 25 \mathrm{~min}\end{array}$ & 1.00 & 0.89 & 0.82 & 0.78 & 0.71 & 0.69 & This paper \\
\hline $\begin{array}{l}0.7 \mathrm{M} \alpha-\mathrm{HIBA}, \\
5 \sim 6 \mathrm{kV}\end{array}$ & 1.00 & 0.90 & 0.85 & 0.79 & 0.66 & 0.57 & 3) \\
\hline
\end{tabular}

3.2 抽出蛍光法によるサマリウム，ユウロピウムの 同時定量

3.2.1 回収率実験 HVPE を経て, 発色された泳 動図のユウロピウム, サマリウムに該当する部分の汇紙 を切り取り, TTA-phen 抽出蛍光法てによって測定し た結果を Table 3 に示した. $20 \sim 800 \mathrm{ng} / 10 \mathrm{ml}$ のユ ウロピウムの平均回収率は $97.8 \%$ ，サマリウムでは $94.0 \%$ で，それぞれの相対標準偏差は 9.6\%, 5.9\%で あった.

3.2.2 実試料への適用超微量のサマリウム, 二 ウロピウムを同時定量するのに TTA-phen（もしくは TOPO) ベンゼン (もしくはへキサン) 抽出蛍光法7) は 高感度, 高選択性などの利点はあるが, 共存イオンによ る蛍光消光作用により ${ }^{8)}$, 全希土類金属酸化物あるいは
Table 3 Recovery of samarium and europium ${ }^{\dagger}$

\begin{tabular}{ccc}
\hline \multirow{2}{*}{$\begin{array}{c}\text { Spotting amounts } \\
\text { of } \mathrm{Sm} \text { or Eu/ng }\end{array}$} & \multicolumn{2}{c}{ Found/ng } \\
\cline { 2 - 3 } Eu & Sm \\
\hline 20 & 21 & 19 \\
80 & 58 & - \\
200 & 85 & - \\
400 & 195 & 180 \\
600 & 330 & 410 \\
800 & 530 & 570 \\
Average & 850 & 710 \\
Recovery(\%) \pm R.S.D.(\%) & $97.8 \pm 9.6$ & $94.0 \pm 5.9$ \\
\hline
\end{tabular}

$\dagger$ Extracted with $10 \mathrm{ml}$ of $5 \times 10^{-5} \mathrm{M}$ TTA- $5 \times 10^{-4} \mathrm{M}$ phenanthroline benzene solution ( $\mathrm{pH}$ 9.5) after electrophoresis.

炭酸カルシウムの含量を一定量以下に制御しなければな らない, 従って, 蛍光法の感度は高いとしても, 実試料 に適用すると，実際に測定しうるサマリウム，ニウロピ ウムの量は制限されてしまう。本法では, $\mathrm{Fe}^{3+}, \mathrm{Sc}^{3+}$, $\mathrm{Y}^{3+}$ など消光作用の非常に強い共存イオン並びに大量 に存在する $\mathrm{La}^{3+}, \mathrm{Ce}^{3+}$ などの他の希土類金属イオン が HVPE で分離されるので, 抽出蛍光法で超微量のサ マリウム、ユウロピウムの 同時定量が 精度よく行われ る. Table 4 に本法を混合希土類金属酸化物試料に適 用した結果を示した. HVPE 抽出蛍光法の併用により,

Table 4 Determination of europium and samarium by HVPE-fluorometry

\begin{tabular}{|c|c|c|}
\hline \multirow{2}{*}{$\begin{array}{l}\text { Composite rare earth } \\
\text { oxides } / \mu g\end{array}$} & \multicolumn{2}{|c|}{ Found/ $/ \mu g$} \\
\hline & $\mathrm{Eu}_{2} \mathrm{O}_{3}$ & $\mathrm{Sm}_{2} \mathrm{O}_{3}$ \\
\hline No. $1 \quad 2.7$ & & \\
\hline $\mathrm{La}_{2} \mathrm{O}_{3} 0.24, \mathrm{CeO}_{2} 0.25$ & 0.23 & 0.21 \\
\hline $\mathrm{Sc}_{2} \mathrm{O}_{3} \quad 0.31, \mathrm{Y}_{2} \mathrm{O}_{3} \quad 0.25$ & 0.24 & 0.22 \\
\hline $\begin{array}{l}\mathrm{Sm}_{2} \mathrm{O}_{3} 0.23, \mathrm{Eu}_{2} \mathrm{O}_{3} \\
\mathrm{Fe}_{2} \mathrm{O}_{3}\end{array}$ & 0.23 & \\
\hline No. $2 \quad 1.3$ & & \\
\hline $\mathrm{La}_{2} \mathrm{O}_{3}$ 0.26, $\mathrm{CeO}_{2}$ 0.27, & 0.025 & 0.24 \\
\hline $\mathrm{Sc}_{2} \mathrm{O}_{3} \quad 0.03, \quad \mathrm{Y}_{2} \mathrm{O}_{3} \quad 0.03$ & 0.024 & 0.26 \\
\hline $\begin{array}{l}\mathrm{Sm}_{2} \mathrm{O}_{3} 0.26, \mathrm{Eu}_{2} \mathrm{O}_{3} 0.023 \\
\mathrm{Fe}_{2} \mathrm{O}_{3} 0.40\end{array}$ & 0.026 & 0.26 \\
\hline No. $3 \quad 1.1$ & & \\
\hline $\mathrm{La}_{2} \mathrm{O}_{3} \quad 0.50, \mathrm{CeO}_{2} 0.03$ & - & 0.023 \\
\hline $\mathrm{Sc}_{2} \mathrm{O}_{3} \quad 0.003, \quad \mathrm{Y}_{2} \mathrm{O}_{3} \quad 0.51$ & & 0.032 \\
\hline $\mathrm{Sm}_{2} \mathrm{O}_{3} 0.026, \mathrm{Fe}_{2} \mathrm{O}_{3} 0.04$ & & 0.025 \\
\hline
\end{tabular}


$0.023 \mu \mathrm{g}$ の酸化ユウロピウム(III) 及び $0.026 \mu \mathrm{g}$ の酸 化サマリウム (III) が精度よく测定されて拉り，本法の 実用性がうかがわれる。

終わりに，本研究は中国科学院科学基金並びに中国河 北省科学技術委員会研究助成金によって行ったものであ り，記して感謝の意を表する。

\section{文献}

1) H. K. Huang, S. W. PANG, S. G. LIANG : Science Record, New Ser., 3, 469 (1959).

2) M. Lederer : Anal. Chim. Acta, 11, 145 (1954).

3) K. Bächmann : Radiochim. Acta, 4, 124 (1965).

4) F. Grass, R. Kittl : Mikrochim. Acta, 1971, 371.

5) K. Aitzetmüller, K. Buchtela, F. Grass, F. Hecht : Mikrochim. Acta, 1966, 1101.

6) N. Miekeley, I. B. de Alleluia : Mikrochim. Acta, 1980, 475 .

7) 黄 漢国，平木敬三，西川泰治：分化，30，452 (1981).

8) 黄 漢国, 平木敬三, 西川泰治 : 近畿大学理工学 部研究報告, 17, 21 (1982).

$$
\text { 产 }
$$

Separation and determination of traces of samarium and europium by means of high voltage paper electrophoresis-fluorometry. Han-guo HuANG and Xiao-an WANG (Hebei Institute of Mining and Metallurgy, Tangshan city, China)
The separation of rare earth metal ions by high voltage paper electrophoresis(HVPE) using citric acid as electrolyte, and determination of samarium and europium by means of extraction fluorometry with 2thenoyltrifluoroacetone (TTA) and 1, 10-phenanthroline (phen) have been investigated. It has been found that migration distance of rare earth metal ions shortened with increasing atomic number and decreasing ionic radius of tervalent rare earth ions. Light rare earth ions, $\mathrm{La}^{3+}-\mathrm{Ce}^{3+}-\mathrm{Pr}^{3+}-\mathrm{Nd}^{3+}-\mathrm{Sm}^{3+}\left(\mathrm{Eu}^{3+}\right)$, could be separated from each other and the separation of these ions from heavy rare earths as well as from $\mathrm{Fe}^{3+-}-\mathrm{Sc}^{3+-} \mathrm{Y}^{3+}$ could also be achieved by using following conditions: electrolyte, $0.05 \mathrm{M}$ citric acid solution ( $\mathrm{pH} 2.22$ ); voltage applied, $3000 \mathrm{~V}$; separation times, $25 \mathrm{~min}$. The recovery of the samarium and europium is $94.0 \%$ and $97.8 \%$, respectively, in the range of $20 \sim 800 \mathrm{ng} / 10 \mathrm{ml}$ of these ions using TTA-phen benzene extraction fluorometry after HVPE. In this way, mixtures of rare earth oxides are analyzed, $0.023 \mu \mathrm{g}$ of $\mathrm{Eu}_{2} \mathrm{O}_{3}$ and $0.026 \mu \mathrm{g}$ of $\mathrm{Sm}_{2} \mathrm{O}_{3}$ being precisely determined.

(Received February 23, 1985)

\section{Keyword phrases}

separation and determination of samarium and europium; high voltage paper electrophoresis; fluorometry of europium and samarium; 2-thenoyltrifluoroacetone. 